\title{
Blind Rivet and Plastically Formed Joints Strength Analysis
}

\author{
Jacek Mucha ${ }^{1, *}$
}

1 Rzeszow University of Technology, Department of Mechanical Engineering, al. Powstancow Warszawy 8, $35-959$ Rzeszów, Poland

\begin{abstract}
The paper presents the results of shearing test of the joints made by using various joining systems, including the clinching technology. In the shearing test the maximum shearing force was obtained. In the experimental the S350GD steel sheets with thickness of $1 \mathrm{~mm}$ were used. This kind of steel is used to produce cold formed profiles which are used to assembly the structures of industrial and residential facilitates. During the selection of fasteners and joining methods the principal of similar joints geometry features was taken into account.

In addition an analysis of the temperature influence on the blind rivet lap joints strength was presented. The experimental shearing tests were done for four temperatures: $23,400,600$ and $800^{\circ} \mathrm{C}$.
\end{abstract}

Keywords: Joint strength; Shear test; Mechanical joining; Riveting; Clinching; Spot welding.

\section{Introduction}

In recent times in the building industry the use of lightweight steel frame constructions is significantly increasing. One of the main advantages of such constructions are the low weight and simple installation, which reduce the time and thus the cost of construction.

In the case of thin-walled structures there is a wide range of joining methods that can be used. Selection of the joining method depends on several factors: material, strength and technology. Eventually the type and destination of the structure are determining the joining system. Thin-walled structures, with steel profiles, are joined by using various types of fasteners - usually the blind rivets $[1 \div 4]$ or special tubular rivets $[5 \div 8]$. In the case of composite structures the bolts are used $[9 \div 11]$. The profiles with thicker wall can be joined by wide range of fasteners, including special rivets [12].

Riveting with use of blind or tubular rivets is a relatively old joining method, but still often used due to relatively simply rivet producing process. In the thin-walled structures other joining methods, for which the hole preparation is not required such as welding or self-drilling screws, are also used. Self-drilling screw joints required an additional fastener and welding process contributes to the corrosion process in the joint area.

Very important issue of the assembly process development is the development of new joining method, but not always with an appropriate level of joints strength $[1,13]$. The use of joining systems based on mechanical working with pressing process allows to obtain, in an easy way, a very strength joint of materials. Particular importance in the automotive industry is clinching joining process $[14,15]$.

Selection of joining method, which determining the joint construction solution, is a very important phase in the structure designing process $[16,17]$. Safety of the solution is the most important thing and it is the basic factor which should be taken 
into account by constructors as the first. Therefore, they are, and they probably will be, used the joining technologies with use of blind rivets and rivets for closing up. Blind tubular rivets are the one of the representatives of large group of fasteners used to joining thin-walled structures. These types of fasteners provide the high-efficiency of assembly process. In the public building and residential houses construction industry these joints are most widely used, because of the need to ensure a high joint certainty (Fig. 1).

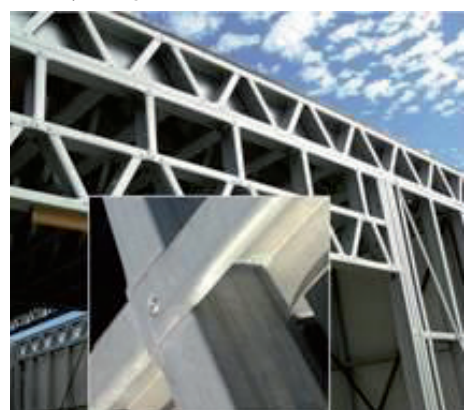

Fig. 1: Trust joint of cold formed profiles with blind rivets.

In the paper a comparison of rivet and clinching joint load capacity was presented. The joint strength comparison was made for ambient temperature $\left(23^{\circ} \mathrm{C}\right)$. The results of experimental research of the single rivet joints strength, in shearing tests, for higher temperatures $\left(400,600,800^{\circ} \mathrm{C}\right)$ were also presented. The research was carried out for zinc coated S350GD steel sheets.

\section{Joint pressing technology}

New solutions of joining technologies including plastic forming by pressing increasingly applied to assembly processes of sheet metal structures [18:22], especially in automotive industry [23]. Joining by pressing as a joining method is still being developed [24]. In the thin-walled structures industry in assembly process many types of joint pressing technology, including clinching, are used: - round joints without additional fastener (Fig. 2),

- round joints with an additional rivet for strengthening the joint (Fig. 3),

- rectangular joint with material incision (Fig. 4), however many other types are known,

- self-piercing rivet (Fig. 5).

Selection of joining method by cold pressing for thin-walled structures is depended on several factors, including:

\section{- joint usefulness in terms:}

$\checkmark$ small initial displacement as a respond on the load force (joint high rigidity)

$\checkmark$ plasticity of its formation.

- availability of knowledge about the joining process and joint design methods,

- availability and reliability of joint quality control methods,

- joining process cost,

- easy of tools handling within a joining part,

- influences on the environment [17, 25].

(a)

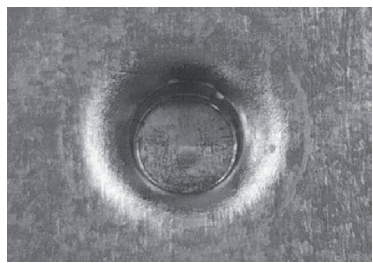

(b)

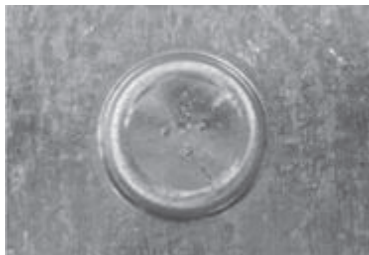

(c)

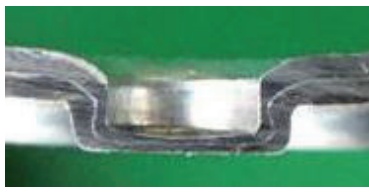

Fig. 2: Clinching joint: (a) punch side view, (b) view of embossment of the die side, (c) cross-section.

(a)

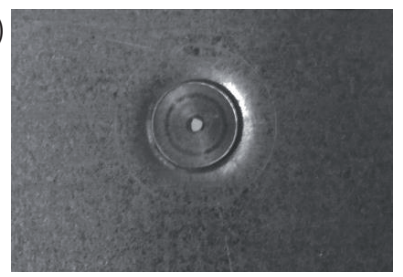

(b)

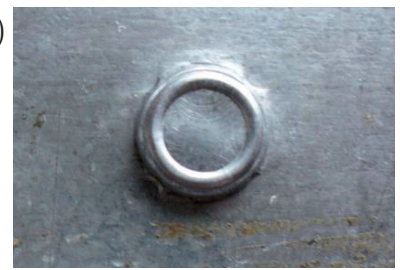

(c)

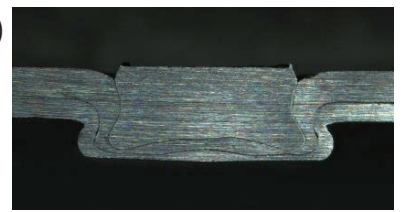

Fig. 3: Clinchriveting joint: (a) punch side view, (b) view of embossment of the die side, (c) cross-section. 

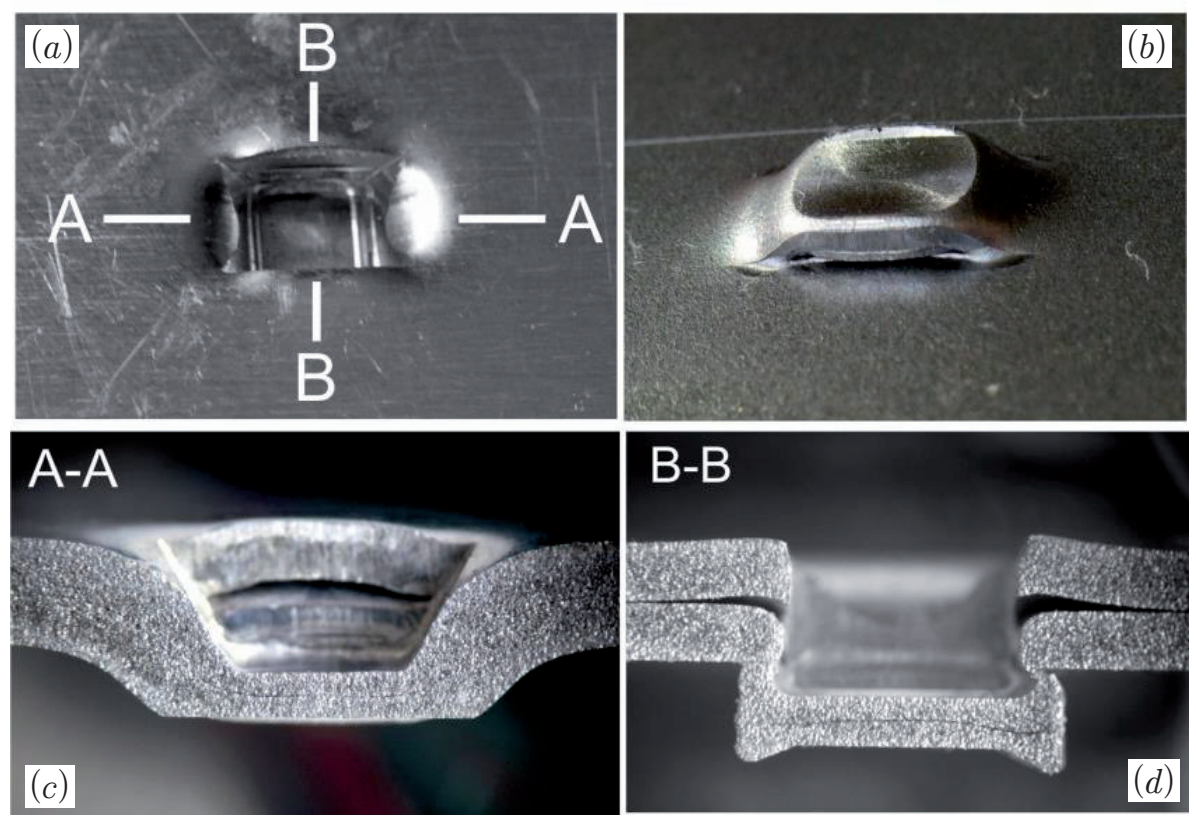

Fig. 4: Rectangular clinching joint with a material incision: (a) punch side view, (b) view of embossment of the die side, (c,d) cross-sections.

(a)

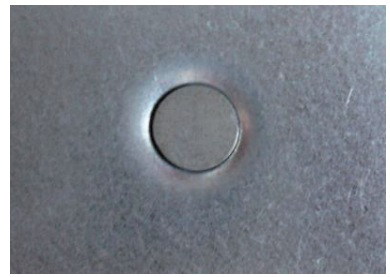

(b)

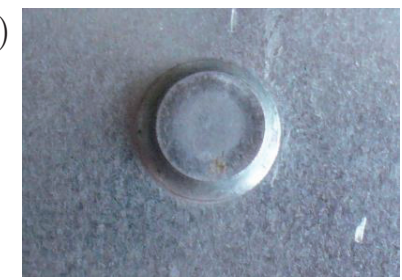

(c)

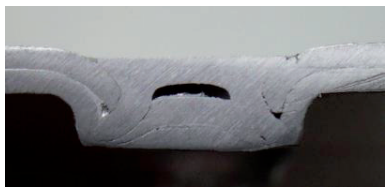

Fig. 5: Self-piercing rivet joint: (a) punch side view, (b) view of embossment of the die side, (c) cross-section.

\section{Experimental material and methods}

For comparison of joints shearing load transferring efficiency the samples of lap joints with blind rivet (A), cold pressed joints: round clinching (B), clinching with additional rivet "clinchrivet" (C), rectangular clinching with material incision (D), self-piercing rivet (E), self-drilling screw joint (F) and welded joint $(\mathrm{G})$ were prepared.
The fastener dimension and tools used in pressing technologies were chosen that the average joints diameter had a value of $5.5 \div 6 \mathrm{~mm}$. Blind rivet was in steel/steel combination - the tubular part and core was made of steel. Rivets used in ClinchRivet and SPR technologies were from Tox Pressotechnik [26] and Böllhoff [27] company offers.

The joining test was performed for steel sheet made of S350GD+Z275 (acc.to EN10326 mat. Number 1.0529) of thickness $1 \mathrm{~mm}$, hot galvanized with coating $275 \mathrm{~g} / \mathrm{m}^{2}$ of thickness $\sim 20 \mathrm{~mm}$. The basic mechanical properties were presented in Table 1, and the chemical composition in Table 2.

Table 1: Mechanical properties of S350GD sheet material.

\begin{tabular}{|c|c|c|c|c|}
\hline $\begin{array}{c}\text { Young's } \\
\text { modulus } \\
\text { E[GPa] }\end{array}$ & $\begin{array}{c}\text { Offsetyield } \\
\text { strength } \\
R_{p 0.2}[\mathrm{MPa}] \\
\text { (minimal } \\
\text { value) }\end{array}$ & $\begin{array}{c}\text { Ultimate tensile } \\
\text { strength } \\
R_{m}[\mathrm{MPa}] \\
\text { (minimal } \\
\text { value) }\end{array}$ & $\begin{array}{c}\text { Elongation } \\
\text { (minimal }[\%] \\
\text { value) }\end{array}$ & $\begin{array}{c}\text { Transverse } \\
\text { bend test 180\% } \\
\text { (minimal } \\
\text { value) }\end{array}$ \\
\hline 2.09 & 350 & 420 & 16 & $2 \mathrm{~g}$ \\
\hline
\end{tabular}

Table 2: Sheet material alloying additions.

\begin{tabular}{|c|c|c|c|c|}
\hline \multicolumn{5}{|c|}{ Chemical composition in \% - maximal values } \\
\hline C & $M n$ & $P$ & $S$ & Si \\
\hline 0.20 & 1.50 & 010 & 0.04 & 0.6 \\
\hline
\end{tabular}


The sheet strips had identical dimensions (115x $40 \mathrm{~mm}$ ), they were appropriate for the shearing test according to ISO/FDIS 12996 standard [28]. Some dimensions in lap joints are defined in EN19931-3 standard [29] and EN1993-1-8 standard [30]. The experimental tests were performed in the Pressed Joint Laboratory of The Department of Mechanical Engineering, The Faculty of Mechanical Engineering and Aeronautics, Rzeszow University of Technology.

Appropriately prepared samples $(A \div \mathrm{G})$ were tested for shear strength until complete sheet separation. The all strength tests were performed in the same conditions of the static test, for the traverse speed of $10 \mathrm{~mm} / \mathrm{min}$ of the tensile testing machine. The jaw grip was $30 \mathrm{~mm}$. The static shearing tests were performed using Instron 3382 machine.

\subsection{Joints strength comparison}

\section{Analysis of Results}

The tested joints quite differently were behaved in the shearing tests. They were required lesser or greater value of energy to complete separation of sheets. During the shearing test of welded joints only weld was destroyed without destroying sheets around the heat-affected zone (Fig. 6). For sheets, with additional coatings, in the welding process problems with appropriate weld joint are occurred. After welding process at the area of electrodesheet contact the weld burn is formed, which in the future time will be the corrosion centre [31].

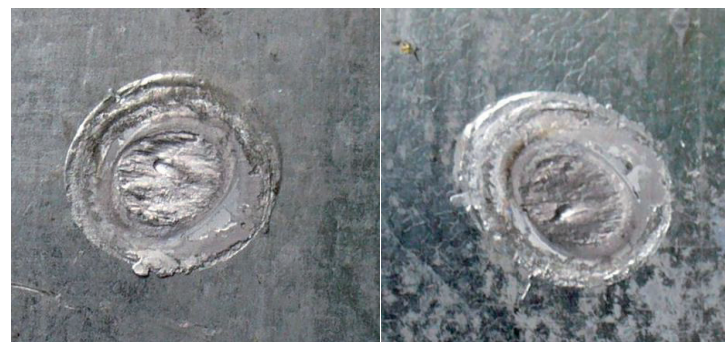

Fig. 6: Spot welded joint after shearing tests - inner side of sheets.

In the case of "Clinching" joints the samples made by using round rigid die were separated by pull out upper sheet from bottom sheet (Fig. 7a). It is one of the failure types of clinching joints [32]. Joints in "ClinchRivet" technology is strengthened by additional rivet pulled in the embossment punch side. In this joint case on the wall embossment material crack was obtained (Fig. 7b) and final separation was done by pull out upper sheet from bottom sheet. For clinching rectangular joint with material incision the greatest damage of embossment was obtained - the interlock was completely destroyed (Fig. 7c).

(a)

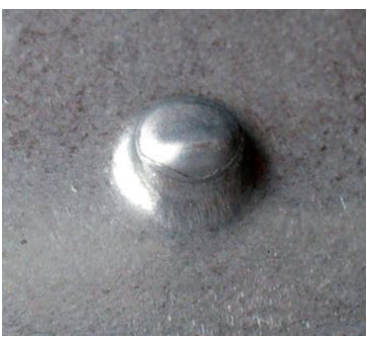

(b)

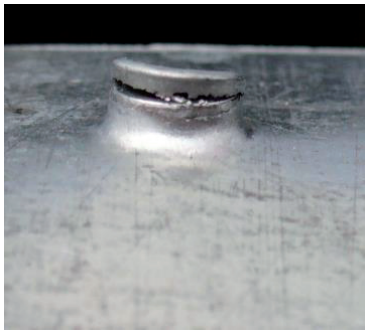

(c)

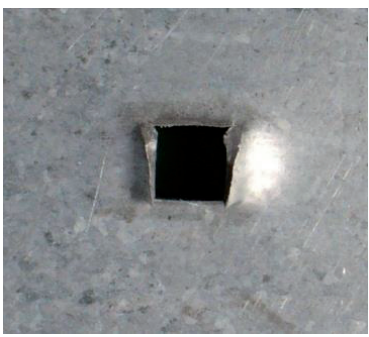

Fig. 7: Overlap joints after shearing tests. View from the inside of clinching joints: (a) round, (b) with additional rivet "ClinchRivet", (c) rectangular with material incision.

To presentation the joint destruction mechanism during the shearing tests causes the sheet deformation the deformed samples of joints with self-drilling screw, with blind rivet and round clinching were presented in Fig. 8. Joint with slef-drilling screw under shearing load in the first phase rotated and then gradually pull out with sheet material cutting. In this case, the maximum displacement for complete separation was required. In some ways, such a solutions with predetermined number of self-drilling screws can still keep the whole thin-walled construction. For blind rivet joint in the first phase was deformed as a result of sheet movements. The rest of the rivet head in the joint tubular part was also moving. 
When it block permanently and it prevented further joints deformation the tubular part of rivet was sheared.
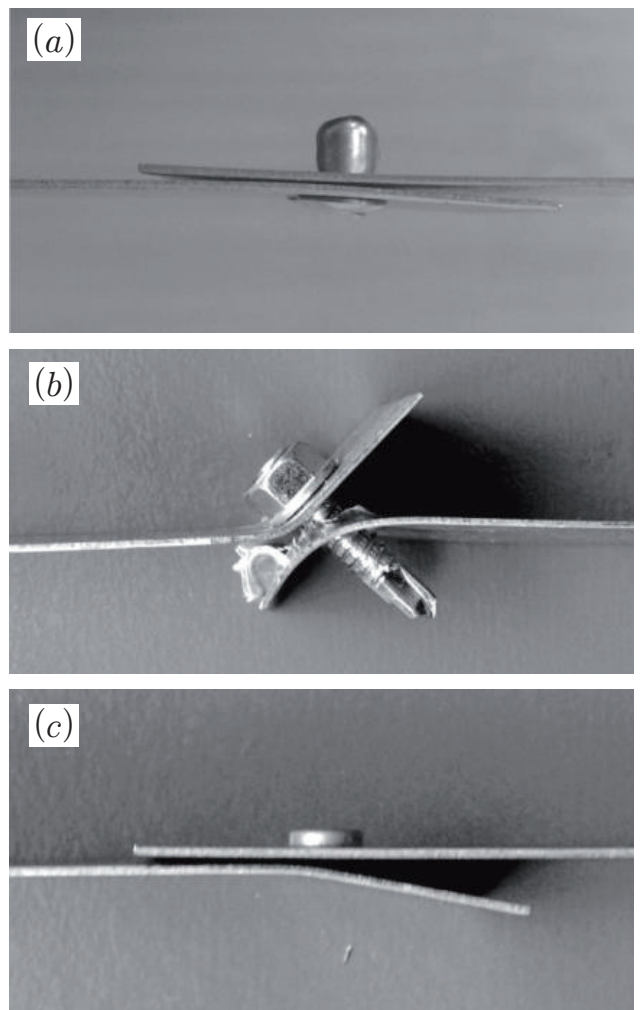

Fig. 8: Deformation of the samples after shearing test of joints: (a) with blind rivet, (b) with self-drilling screw, (c) round clinching.

For joints mad for S350GDS steel sheets lowest shearing force was obtained for the clinching with material incision (ClinchinPR curve) - Fig. 9a. Higher value of shearing force was obtained for round clinching joint (Clinching curve). The highest shearing force was obtained for ClinchRivet joining technology. The maximum load increase of $60 \%$ in comparison to the round clinching joint and of $111 \%$ relatively to the rectangular clinching joint with material incision. Among all the researched joining technology types the ClinchRivet joints had the maximum shear strength. It is the most promising cold pressed joints in terms of load capacity [33].

The load displacement curves from shearing test of lap joints for selected joining by pressing technologies were compared with load displacement curves of conventional joining solutions (Fig. 9b). From the observation of load displacement curves the biggest stiffness had a welded joint - steep curve in initial phase of forcing displacement. Among all the joints for the two clinching joints with additional rivet (CR and SPR) the highest shear strength were obtained. However, thes joining technologies require the use of expensive tools - the head with rivet feed system. The average values of five tests were presented in Fig. 10
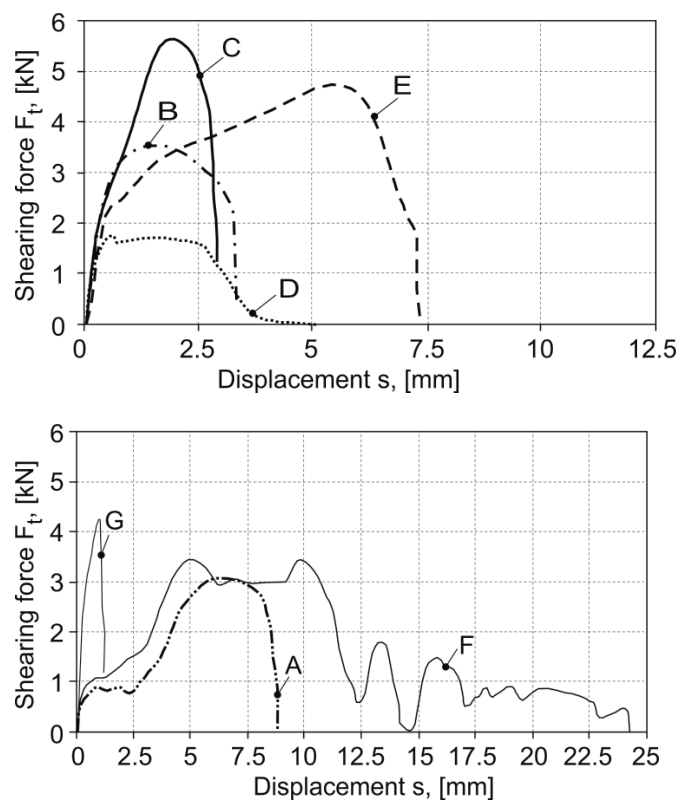

Fig. 9: Force displacement curves from shearing tests of joints (temperature of $23^{\circ} \mathrm{C}$ ): (a) pressing), (b) conventional.

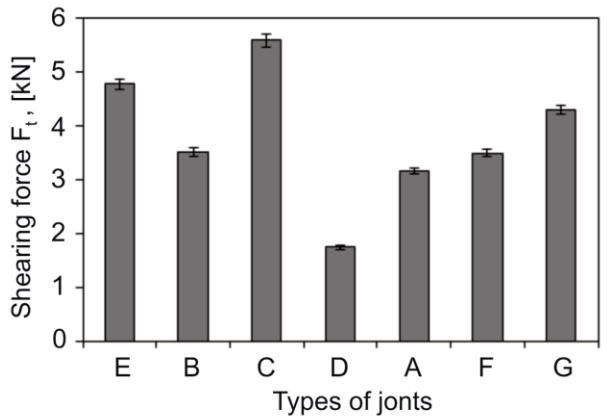

Fig. 10: Average values of the maximum shear strength for different types of joints.

\subsection{Temperature influence on the blind rivet joint strength}

In the case of shear load displacement curve, at the room temperature, a stoop of force changing during the joint loading was observed at value of $800 \div 900 \mathrm{~N}$ (Fig. 11). The load force is around $850 \mathrm{~N}$ with increasing of test machine traverse 
displacement. During the shearing test for displacement between 0,65 $\mathrm{mm}$ and 2,05 $\mathrm{mm}$ the clearance reduction between the rivet and hole was obtained. The rivet head also moved. Further load transfer without tubular part of rivet deformation was not possible. The increase of load force was from mechanism of rivet plastic deformation. Maximum shear strength of blind rivet joint was $3080 \mathrm{~N}$ (Fig. 11). Increase of load temperature to $400^{\circ} \mathrm{C}$ during the shearing test caused the change of the load displacement characteristic of the joint. The oxidation of the zinc coating resulted in blocking of sheet movements by increase of friction and the sheet material thermal expansion effect. Immediately the joint was transferring the load. At the temperature $400^{\circ} \mathrm{C}$ the maximum joint strength was lower about 9\% in relations to the strength at room temperature. Subsequent research was related to the blind rivet joint strength at temperature $600^{\circ} \mathrm{C}$ and $800^{\circ} \mathrm{C}$.

Among all tests the rivet head prevented the shear of the rivet in the plane of sheet contact. The loss of the rivet material cohesion was obtained at the end of the river core (Fig. 12).

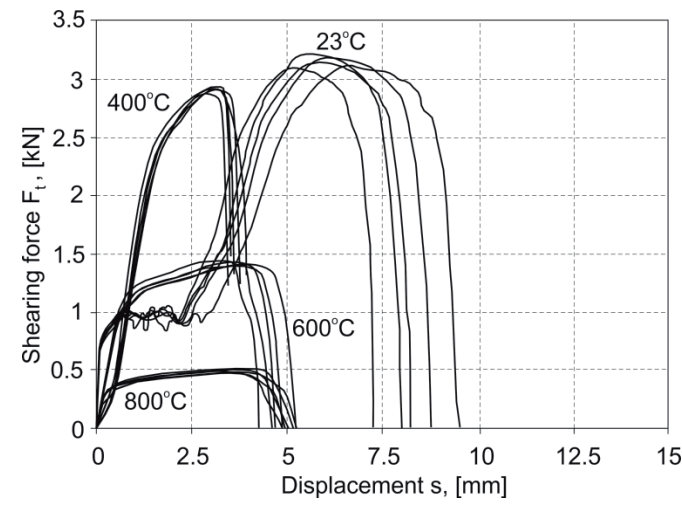

Fig. 11: Load dispalcement curves.

\section{Conclusions}

- For all joining systems a significant differences in load displacement curves were observed. Furthermore, in the case of joining by cold pressing the highest strength was achieved for the ClinchRivet joining system. The ClinchRivet joint strength in comparison of blind rivet joint strength was higher by $72 \%$. Blind rivet joints in load displacement characteristic had a force increase stop due to the relative displacements of sheets. Load displacement curves of welded joint are steepest up to the maximum strength. The lowest initial stiffness of the S350GD sheet joints was obtained for the joints with self-drilling screw. (a)

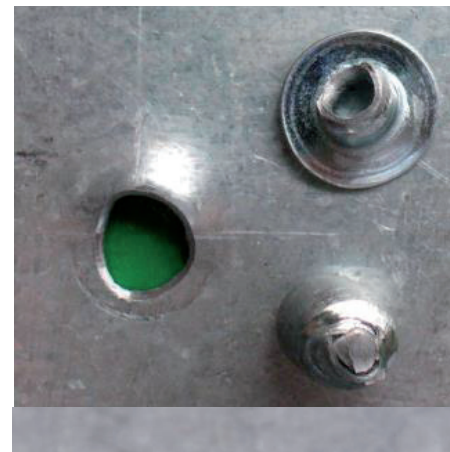

(c)

$(d)$

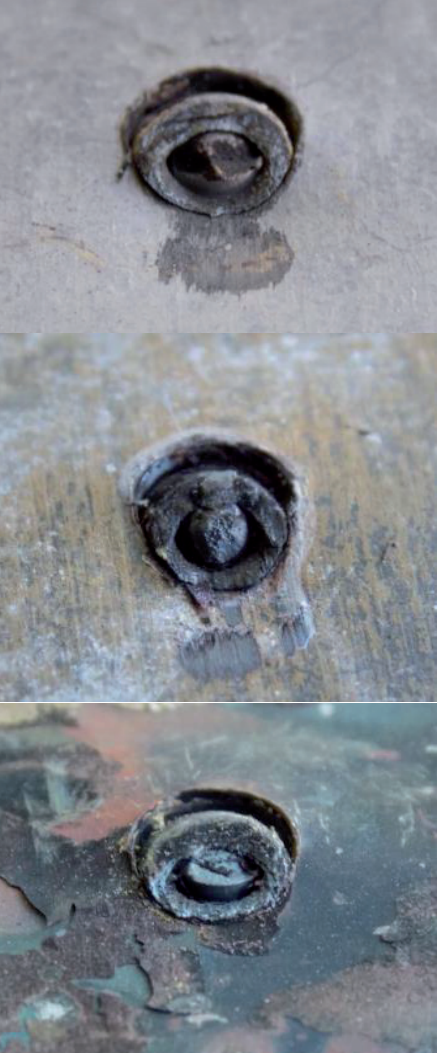

Fig. 12: Macrographs of the cracks surface of the tubular rivet part for the shearing tests temperature: (a) $23^{\circ} \mathrm{C}$, (b) $400^{\circ} \mathrm{C}$, (c) $600^{\circ} \mathrm{C}$, (d) $800^{\circ} \mathrm{C}$.

Joint load capacity decreases very significantly with the increase of the shearing test temperature. This is due to increasing of the thermo-mechanical loads. The higher the temperature of shearing test the less significant differences of load displacement curves were obtained. Increase of temperature significantly influence on the joint strength. The smallest differences in maximum joint strength was obtained for shearing test at temperature $23^{\circ} \mathrm{C}$ and $400^{\circ} \mathrm{C}$. The biggest difference was obtained for temperature increase from $400^{\circ} \mathrm{C}$ to $600^{\circ} \mathrm{C}$. Joint strength tests at high temperatures is important issue for testing the fire resistance of constructions. 


\section{References}

[1] Mucha, J., Witkowski, W. (2013). The experimental analysis of the double joint type change effect on the joint destruction process in uniaxial shearing test. Thin Wall. Struct. Vol.66, p. 39-49.

[2] Bayan, A., Sariffuddin, S., Hanim, O. (2011). Cold formed steel joints and structures-a review. Int. J. Civil Struct. Eng. Vol. 2(2), p. 621-634

[3] Lu, W., Mäkeläinen, P., Outinen, J., Ma, Z. (2011). Design of screwed steel sheeting connection a tambient and elevated temperatures. Thin Wall. Struct. Vol. 49, p. 1526-1533.

[4] Childs, P. (2014). Fastening and Power Screws in: Mechanical Design Engineering Handbook, Elsevier Ltd., 2014, p 677-719. ISBN: 978-0-08-097759-1.

[5] Moroni, F., Pirondi, A., Kleiner, F. (2010). Experimental analysis and comparison of the strength of simple and hybrid structural joints. Int. J. Adhes. Adhes. Vol. 30, p. 367-379.

[6] Di Franco, G., Fratini, L., Pasta, A. (2012). Influence of the distance between rivets in self-piercing riveting bonded joints made of carbon fiber panels and AA2024 blanks. Mater. Des. Vol. 35, p. 342-349.

[7] Di Franco, G., Fratini, L., Pasta, A. (2013). Analysis of the mechanical performance of hybrid (SPR/bonded) single-lap joints between CFRP panels and aluminum blanks. Int. J. Adhes. Adhes. Vol. 41, p. 24-32.

[8] Masahito Ueda, M., Miyake, S., Hasegawa, H., Hirano, Y. (2012). Instantaneous mechanical fastening of quasi-isotropic CFRP laminates by a self-piercing rivet. Compos. Struct. Vol. 94, p. 3388-3393.

[9] Dano, ML., Gendron, G., Picard A. (2000). Stress and failure analysis of mechanically fastened joints in composite laminates. Compos. Struct. Vol. 50(3), p. 287-96.

[10] Matsuzaki, R., Shibata, M., Todoroki, A. (2008). Improving performance of GFRP/aluminum single lap joints using bolted/co-cured hybrid method. Compos. Part A-Appl S. Vol. 39, p. 154-163.

[11] Kolesnikov, B., Herbeck, L., Fink, A. (2008). CFRP/titanium hybrid material for improving composite bolted joints. Compos. Struct. Vol. 83, p. 368-380.

[12] Słowiński, K., Wuwer, W. (2016). Blind-bolted shear connections for axially compressed RHS columns strengthened with open sections. J. Constr. Steel Res. Vol. 127, p. 15-27.

[13] Di Lorenzo, G, Landolfo, R. (2004). Shear experimental response of new connecting systems for cold-formed structures. J. Constr. Steel Res. Vol. 60(3-5), p. 561-579.

[14] Spišák, E., Kaščák, L. (2014). Mechanical Joining of Steel Sheets in Automotive Industry. Acta Mechanica Slovaca, 18(3-4); 6-13.

[15] Spišák E., Kaščák L., Joining Car Body Steel Sheets Using the Clinching Method, Acta Mechanica Slovaca. Vol. 15(1), p. 28-
35.

[16] LeBacq, C., Brechet, Y., Shercliff, H.R., Jeggy, T., Salvo, L. (2002). Selection of joining methods in mechanical design. Mater. Des. Vol. 23, p. 405-416.

[17] Neugebauer, R., Todtermuschke, M., Mauermann, R., Riedel F., Overview on the state of development and the application potential of dieless mechanical joining processes. Arch. Civ. Mech. Eng. Vol. 8(4), p. 135-148.

[18] Neugebauer, R., Dietrich, S., Kraus, C. (2007). Dieless clinching and dieless rivet-clinching of Magnesium. Key Eng. Mater. Vol. 344, p. 693-698.

[19] Pedreschi, R., Sinha, B., Davies, R. (1997). Advanced connection techniques for cold-formed steel structures. J. Struct. Eng. Vol. 123(2), 138-144.

[20] Varis, JP. (2002). The suitability of round clinching tools for high strength structural steel. Thin Wall. Struct. Vol. 40(3), p. 225-238.

[21] Pedreschi, R., Sinha, B., Davies, R., Lennon, R. (1998). Factors Influencing the Strength of mechanical clinching. in: Fourteenth International Specialty Conference on ColdFormed Steel Structures St. Louis, Missouri U.S.A., October 15-16,1998.

[22] Coppieters, S., Lava, P., Baes, S., Sol, H., Van Houtte, P., Debruyne, D. (2012). Analytical method to predict the pull-out strength of clinched connections. Thin Wall. Struct. Vol. 52, p. 42-52.

[23] Kaščák, L., Mucha, J., Slota, J., Spišák, E. (2013). Application of modern joining methods in car production. Wydawnictwo Oficyny Politechniki Rzeszowskiej. Rzeszów. ISBN : 978-837199-903-8.

[24] Mucha, J. (ed.). (2015). Research and development trends of cold joining by clinching. Wydawnictwo Oficyny Politechniki Rzeszowskiej. Rzeszów. ISBN: 978-83-7934-020-0.

[25] Lennon, R., Pedreschi, R., Sinha, B.P. (1999). Comparative study of some mechanical connections in cold formed steel. Constr. Build. Mater. Vol. 13, p. 109-116.

[26] www.tox-pl.com (20.11.2016).

[27] www.bollhoff.pl (21.11.2016).

[28] ISO/FDIS 12996. (2013). Mechanical joining - Destructive testing of joints - Specimen dimensions and test procedure for tensile shear testing of single joints.

[29] EN1993-1-3. (2005). Eurocode 3. Design of steel structures. Part 1-3: General rules - Supplementary rules for coldformed members and sheeting.

[30] EN1993-1-8. (2005). Eurocode 3. Design of steel structures. Part1-8: Design of joints.

[31] Spišák, E., Kaščák, L., Brezinová, J., Viňáš, J., Draganovská, D., Jankura, D. (2011). Influence of Corrosive Environment on the Surface Quality of Spot Welds. Acta Mechanica Slovaca. Vol. 15(4), p. 20-25. 
Acta Mechanica Slovaca

Journal published by Faculty of Mechanical Engineering - Technical University of Košice

[32] Mucha, J., Kaščák, L’., Spišák, E. (2011). Joining the car-body sheets using clinching process with various thickness and mechanical property arrangements. Arch. Civ. Mech. Eng. Vol. 11(1), p. 135-148.

[33] Mucha, J., Kaščák, L.., Spišák, E. (2013). The experimental analysis of forming and strength of clinch riveting sheet metal joint made of different materials. Adv.Mech. Eng. DOl: 10.1155/2013/848973.

\section{Biographical notes}

Eng. Jacek Mucha, PhD., is an employee of Department of Mechanical Engineering, The Faculty of Mechanical Engineering and Aeronautics, Rzeszow University of Technology. He works as an associate professor in Rzeszow University of Technology. PhD degree in technical sciences received in 2004, and qualifying as assistant professor in 2014 in the Mechanics and Mechanical Engineering discipline. In his achievements he has got more than one hundred publications. He is an author and co-author of several patents. In Poland actively participates in the work for scientific publishers, in several of them as a reviewer. He is also a reviewer of The National Centre for Research and Development, for which he developed several opinions of research projects.

The main issues of scientific research are related to: the analysis of the joints strength used in mechanical engineering, tool wear in metal forming processes and modern manufacturing processes. He also deals with the issues of strength analysis of the mechanical structures by using finite element method. 